\title{
Phospholipid composition of tissues in calves suffering from nutritional muscular dystrophy
}

\author{
BY RITVA POUKKA \\ Department of Biochemistry, College of Veterinary Medicine, Helsinki, Finland
}

(Received 30 August 1967-Accepted I8 March 1968)

\begin{abstract}
1. The distribution of different phospholipid fractions in the heart muscle, skeletal muscle and liver of healthy calves and of calves suffering from nutritional muscular dystrophy was investigated. In healthy calves the proportion of phosphatidyl choline was lower in the heart muscle phospholipids than in the phospholipids of the other tissues, the proportion of cardiolipin was highest in the heart muscle phospholipids and lowest in the liver phospholipids. The proportion of lysophosphatidyl choline tended to be higher in the liver phospholipids than in the phospholipids of other tissues.

2. Liver phospholipids from diseased animals contained less phosphatidyl choline and more cardiolipin than the liver phospholipids from healthy animals.

3. In the healthy animals the fatty acid patterns of phosphatidyl choline and phosphatidy] ethanolamine were the same as those found previously by other investigators. There was a preponderance of stearic and arachidonic acids in phosphatidyl ethanolamine and palmitic and oleic acids in phosphatidyl choline. However, in the phosphatidyl choline of liver the concentration of stearic acid was higher than that of palmitic acid.

4. In calves with nutritional muscular dystrophy the fatty acid patterns of phosphatidyl choline and phosphatidyl ethanolamine were different from those in healthy animals. The linoleic acid concentration was increased in muscular dystrophy in both phospholipid fractions of all tissues investigated and the concentration of arachidonic acid was significantly increased in the phosphatidyl ethanolamine of skeletal muscle. The concentration of stearic acid was increased in the phosphatidyl ethanolamine of heart muscle and skeletal muscle, whereas the concentrations of oleic and palmitoleic acids were decreased in both phospholipid fractions of these tissues. In liver, heart, and skeletal muscle the concentration of palmitoleic acid was decreased in both phospholipid fractions.
\end{abstract}

In an earlier investigation (Poukka, 1966) certain differences were found in the fatty acid composition of the total phospholipids of the heart muscle, skeletal muscle and liver from healthy calves and from calves suffering from nutritional muscular dystrophy. Because the fatty acid compositions of different phospholipid fractions are known to be highly specific (van Deenen, r965), it is possible that these observed differences (Poukka, 1966) were a reflection of the differences in the relative quantities of various types of phospholipids. The purpose of this investigation was to study whether any such differences in relative quantities could be found, or whether the differences found in fatty acid composition of the total phospholipid were due to differences in fatty acid compositions of individual phospholipid fractions. Because phosphatidyl choline and phosphatidyl ethanolamine constitute the major part of the total phospholipids of the tissues, the fatty acid patterns of only these two fractions were investigated.

\section{EXPERIMENTAL}

Material. The calves examined were of the Finnish and Ayrshire breeds; they came from the province of Pohjanmaa where muscular dystrophy occurs enzootically and where the selenium content of the forage has been found to be low (Oksanen, 1965). 
The tissue samples were obtained from the slaughter-house of the city of Helsinki immediately after the slaughter of the calves. Nothing exact is known about the diets of the animals. The main diet of young calves in Finland is whole milk and skim milk, although milk substitutes containing bone fat and tallow have come into use recently. However, on many farms whole milk and skim milk form the main foods of calves during the first weeks of life.

The age of the animals examined varied from 1 to 4 weeks. Their slaughter weights ranged from $I_{4}$ to $29 \mathrm{~kg}$ and the weights of the hearts from I 50 to $393 \mathrm{~g}$. The diagnosis of muscular dystrophy was made only macroscopically. Animals which showed widespread, symmetrically bilateral lesions of the muscles were considered to be diseased.

Extraction of lipids. The lipids were extracted according to the method of Bligh \& Dyer (1959) immediately after the slaughter of the animals.

Fractionation of phospholipids. The method used for fractionation of phospholipids was essentially that of Skipski, Peterson \& Barclay (1964). The glass plates were coated with a layer (0.25 mm thick) of silica gel (Kieselgel G; Merck, Darmstadt, Germany), air-dried and then activated at I IO-I I $5^{\circ}$ for $\mathrm{I} h$ before use. The lipid samples dissolved in methanol-chloroform $(2: \mathrm{I}, \mathrm{v} / \mathrm{v})$ were applied to the plate with an Agla syringe (Burroughs Wellcome \& Co., London). Every sample was investigated in duplicate and, for the determination of phosphorus, the lipid solutions of 20 and $10 \mu 1$, containing about 24 and $12 \mu \mathrm{g}$ of lipid phosphorus respectively, were applied to the plate. The smaller amount was for the determination of phosphatidyl choline and phosphatidyl ethanolamine. The phosphorus content of the other phospholipid fractions was determined from the larger samples. The spots were detected by exposure to iodine vapour. The spots were identified by comparison of their $R_{f}$ values with those of authentic substances as standards, and also by spraying the plates with the ninhydrin and Dragendorf reagents (Stahl, ${ }_{1965}$ ). The spots were removed and digested directly according to the method of Doizaki \& Zieve (1963). For phosphorus determination the method of Bartlett (r959) was used. The optical density was read at $830 \mathrm{~nm}$ in a Hitachi Perkin-Elmer spectrophotometer.

For determination of the fatty acid composition of phosphatidyl choline and phosphatidyl ethanolamine, plates of silica gel $(0.5 \mathrm{~mm}$ thick) were used, and the samples were applied as a band about $2 \mathrm{~cm}$ from the edge of the plate; $0.01 \%$ of butyl hydroquinone ( 1,4 -dihydroxy-2-tert.-butyl benzene) was added to the developing solvent mixture (Neudoerffer \& Lea, I966). The plates were exposed to iodine vapour for about I 5 sec (Malins, I966). Phosphatidyl choline and phosphatidyl ethanolamine were eluted from the bands of silica gel with ${ }_{5} 5 \mathrm{ml}$ of each of the following solvent mixtures: chloroform-methanol I : I $(\mathrm{v} / \mathrm{v})$, chloroform-methanol $\mathrm{I}: 3(\mathrm{v} / \mathrm{v})$ and pure chloroform. The solvents were evaporated under reduced pressure in a rotary film evaporator and the methyl esters of the fatty acids present in phospholipids were prepared by the transesterification procedure of Stoffel, Chu \& Ahrens (r959).

Gas-liquid chromatography. A Perkin-Elmer Gas Chromatograph Model 800 equipped with a flame ionization detector was used. The analysis of fatty acid methyl esters was carried out on $2 \mathrm{~m}$ stainless steel columns, 0.25 in. in internal diameter, 
packed with $12 \%(\mathrm{w} / \mathrm{w})$ butandiolsuccinate (Applied Science Laboratories, State College, PA.) on Chromosorb W. The following operating conditions were used: carrier gas flow $60 \mathrm{ml} / \mathrm{min}$; temperatures, injection part $275^{\circ}$, column $180^{\circ}$, detector $235^{\circ}$. The retention times and the carbon numbers (Woodford \& van Gent, 1959-60) of the major fatty acids were calculated and compared with the values obtained for standard preparations of fatty acid methyl esters. Perkin-Elmer Integrator D 24 was used to measure the peak areas. The results are expressed as a percentage contribution of the major fatty acid methyl esters of the total area of all peaks.

Student's $t$ test was used for the statistical analysis, a probability of $\leqslant 0.05$ being accepted as revealing a significant difference.

\section{RESULTS}

Differences in the proportions of the various phospholipid fractions in the tissues obtained from healthy animals. As is shown in Table $\mathbf{1}$, the proportion of phosphatidyl choline was somewhat lower in the heart muscle phospholipids than in the phospholipids of the other tissues. The proportion of cardiolipin was highest in the heart muscle phospholipids and lowest in the liver phospholipids. Lysophosphatidyl choline tended to be somewhat higher in the liver phospholipids than in the phospholipids of the other tissues. No differences were found between the tissues investigated in the proportions of the other phospholipid fractions.

Table I. Composition (\% of the total phospholipid) of phospholipids from healthy calves and from calves suffering from muscular dystrophy

(Each value represents the mean with its standard error for duplicate experiments

\begin{tabular}{|c|c|c|c|c|c|c|c|c|}
\hline \multicolumn{9}{|c|}{ from ten samples) } \\
\hline animals & $\mathrm{PhC}$ & PhEA & $\mathrm{S}$ & C & $\mathrm{PhS}$ & $\mathrm{PhI}$ & LphC & Unknown \\
\hline $\begin{array}{l}\text { Heart: } \\
\text { Healthy } \\
\text { Diseased }\end{array}$ & $\begin{array}{l}43 \cdot 7 \pm 1 \cdot 3 \\
42 \cdot 4 \pm 1 \cdot 4\end{array}$ & $\begin{array}{l}30.1 \pm 0.9 \\
29.5 \pm 1.0\end{array}$ & $\begin{array}{l}8.0 \pm 0.7 \\
8.7 \pm 1.0\end{array}$ & $\begin{array}{l}8.3 \pm 0.5 \\
9.2 \pm 0.9\end{array}$ & $\begin{array}{l}3.3 \pm 0.5 \\
3.9 \pm 0.5\end{array}$ & $\begin{array}{l}I \cdot 1 \pm 0.2 \\
1 \cdot 7 \pm 0.2\end{array}$ & $\begin{array}{l}3 \cdot 2 \pm 0.6 \\
2 \cdot 9 \pm 0.6\end{array}$ & $\begin{array}{l}2.4 \pm 0.5 \\
1.8 \pm 0.5\end{array}$ \\
\hline $\begin{array}{l}\text { Skeletal mus } \\
\text { Healthy } \\
\text { Diseased }\end{array}$ & $\begin{array}{l}\text { scle: } \\
49 \cdot 4 \pm 2 \cdot 3 \\
48 \cdot 1 \pm 2 \cdot 4\end{array}$ & $\begin{array}{l}29 \cdot 0 \pm 2 \cdot 2 \\
27 \cdot 7 \pm 1 \cdot 4\end{array}$ & $\begin{array}{l}7.5 \pm 0.9 \\
9.8 \pm 1.2\end{array}$ & $\begin{array}{l}5.6 \pm 0.5 \\
4 . x \pm 0.6\end{array}$ & $\begin{array}{l}3.2 \pm 0.8 \\
3.0 \pm 0.7\end{array}$ & $\begin{array}{l}1.1 \pm 0.3 \\
0.8 \pm 0.2\end{array}$ & $\begin{array}{l}2.6 \pm 0.4 \\
3.8 \pm 0.7\end{array}$ & $\begin{array}{l}1 \cdot 7 \pm 0.6 \\
2 \cdot 7 \pm 0.6\end{array}$ \\
\hline $\begin{array}{l}\text { Liver: } \\
\text { Healthy } \\
\text { Diseased }\end{array}$ & $\begin{array}{l}49^{\circ} 7 \pm x \cdot 6 \\
44^{\circ} 3 \pm I \cdot 1\end{array}$ & $\begin{array}{l}29^{\prime} 2 \pm 1 \cdot 3 \\
30 \cdot 2 \pm 1 \cdot 1\end{array}$ & $\begin{array}{l}7 \cdot 8 \pm 0.6 \\
9 \cdot 0 \pm 0.5\end{array}$ & $\begin{array}{l}2 \cdot 0 \pm 0.4 \\
4.0 \pm 0.4\end{array}$ & $\begin{array}{l}3.0 \pm 0.7 \\
4.6 \pm 0.6\end{array}$ & $\begin{array}{l}I \cdot 5 \pm .02 \\
x \cdot 5 \pm 0.2\end{array}$ & $\begin{array}{l}4.9 \pm 0.7 \\
3.8 \pm 0.8\end{array}$ & $\begin{array}{l}2 \cdot 0 \pm 0.5 \\
2 \cdot 7 \pm 0.9\end{array}$ \\
\hline $\begin{array}{c}\text { Differences s } \\
5 \% \text { level } \\
1 \% \text { level }\end{array}$ & $\begin{array}{c}\text { significant } \\
\text { Liver } \\
-\end{array}$ & - & - & Liver & - & - & - & - \\
\hline
\end{tabular}

$\mathrm{PhC}=$ phosphatidyl choline, $\mathrm{PhEA}=$ phosphatidyl ethanolamine, $\mathrm{S}=$ sphingomyelin, $\mathrm{C}=$ cardiolipin, $\mathrm{PhS}=$ phosphatidyl serine, $\mathrm{PhI}=$ phosphatidyl inositol, $\mathrm{LphC}=$ lysophosphatidyl choline.

Differences in the proportions of the various phospholipid fractions in the tissues of healthy and diseased animals. As shown in Table I, the liver phospholipids from diseased animals contained less phosphatidyl choline and more cardiolipin than the liver phospholipids from healthy animals (differences were significant at the 5 and $\mathrm{I} \%$ levels, respectively). The proportion of sphingomyelin tended to be high in the 
phospholipids of skeletal muscle and liver from diseased animals, but the differences were not significant. No differences in the concentration of phospholipid fractions from the heart muscle were found.

Fatty acid compositions of phosphatidyl choline and phosphatidyl ethanolamine in the tissues of healthy animals. As shown in Table 2, the concentrations of palmitic acid were high in all the phosphatidyl choline fractions, whereas the concentrations of stearic acid were high only in the phosphatidyl ethanolamine fractions (Table 3), except in the liver, where the concentration of stearic acid was high in both phospholipid fractions. Oleic acid was present in higher concentrations in the phosphatidyl choline, although its concentration was very variable, as revealed by the high values for standard errors. The concentration of linoleic acid was equally high in both phospholipid fractions, but the concentration of arachidonic acid was greater in the phosphatidyl ethanolamine fraction.

Table 2. Mean values ( $\%$ by weight) with their standard errors for the proportions of the major fatty acids present in the phosphatidyl choline from the tissues of healthy calves and calves suffering from muscular dystrophy

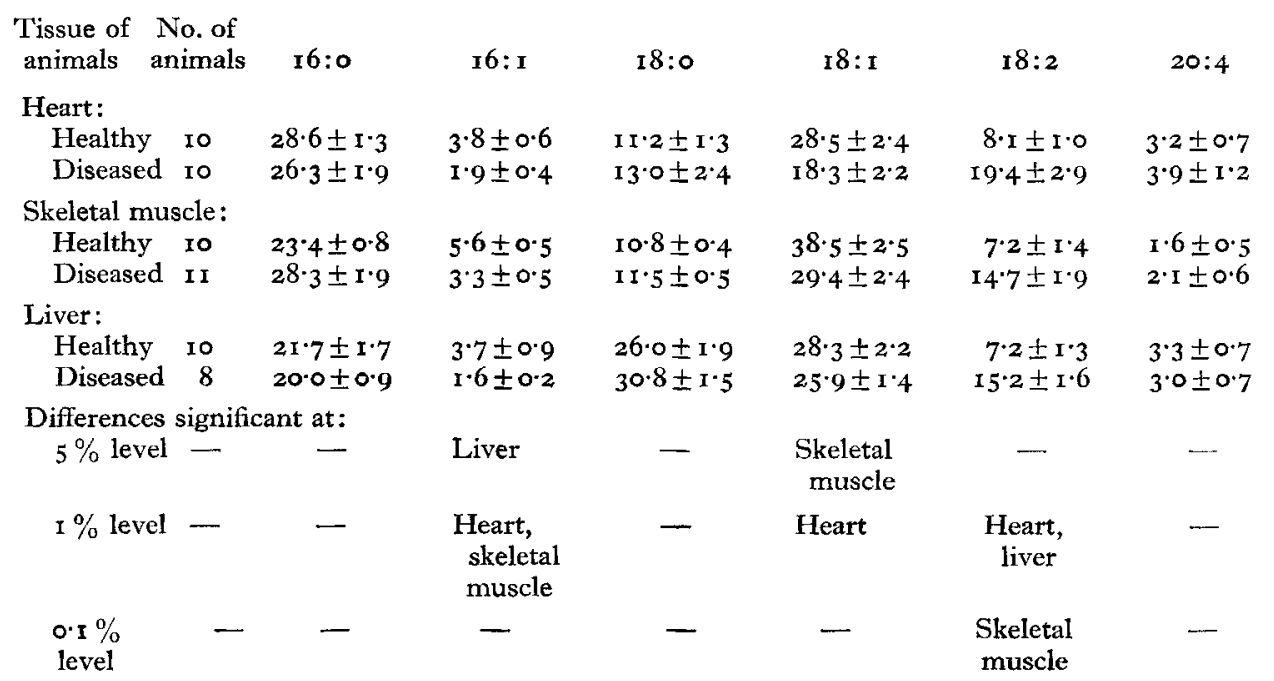

$16: 0=$ palmitic acid, $I 6: \mathrm{I}=$ palmitoleic acid, $\mathrm{I} 8: 0=$ stearic acid, $18: 1=$ oleic acid, $18: 2=$ linoleic acid, 20:4 = arachidonic acid.

Differences in the fatty acid patterns of phosphatidyl choline and phosphatidyl ethanolamine obtained from the tissues of healthy and diseased animals. As shown in Tables 2 and 3 , the most marked difference in the fatty acid composition between tissues from healthy calves and diseased calves was in the concentration of linoleic acid in both the phosphatidyl choline and phosphatidyl ethanolamine fractions; in these two phospholipid fractions the concentrations of linoleic acid were two to three times higher in tissues from diseased animals than in tissues from healthy animals. For the linoleic acid of phosphatidyl ethanolamine of the heart muscle and for that of phosphatidyl choline of the skeletal muscle the differences were significant at the $0.1 \%$ level. The other differences found in linoleic acid concentrations were significant at the $x \%$ level. 
Similar differences were observed in the concentrations of arachidonic acid in the phosphatidyl ethanolamine of skeletal muscle $(P<0.05)$, whereas in the liver no difference was found; in the heart muscle the difference was not statistically significant. The rise in the concentration of linoleic acid in the tissue phospholipids of diseased animals was accompanied by a decrease in the concentration of oleic acid, except in the liver where the difference was not significant. The difference in the oleic acid concentration of the phosphatidyl choline of the heart muscle was significant at the $\mathrm{I} \%$ level and that of the phosphatidyl ethanolamine at the $5 \%$ level. The corresponding differences for the skeletal muscle were significant at the $5 \%$ and the $0.1 \%$ levels.

In the phosphatidyl ethanolamine fraction, the concentration of stearic acid was increased in the heart muscle $(P<0.01)$ and skeletal muscle $(P<0.01)$ of diseased animals, whereas in the liver the difference was not statistically significant. The concentration of palmitoleic acid was decreased in the tissue phospholipids of diseased animals. The decrease was however not statistically significant in the phosphatidyl ethanolamine fraction of the skeletal muscle.

Table 3. Mean values ( $\%$ by weight) with their standard errors for the proportions of the major fatty acids present in the phosphatidyl ethanolamine from the tissues of healthy calves and calves suffering from muscular dystrophy

\begin{tabular}{|c|c|c|c|c|c|c|c|}
\hline $\begin{array}{l}\text { Tissue of } \\
\text { animals }\end{array}$ & $\begin{array}{l}\text { No. of } \\
\text { animals }\end{array}$ & $16: 0$ & $16: 1$ & $18: 0$ & $x 8: 1$ & $18: 2$ & $20: 4$ \\
\hline \multicolumn{8}{|l|}{ Heart: } \\
\hline Healthy & I0 & I I.० $\pm x \cdot 6$ & $4.2 \pm 0.3$ & $19 \cdot 2 \pm I \cdot 6$ & $19.5 \pm 2.5$ & $8.3 \pm 0.8$ & $\mathrm{II} \cdot 3 \pm \mathrm{I} \cdot 4$ \\
\hline Diseased & I I & $7.7 \pm 0.6$ & $2 \cdot 1 \pm 0.2$ & $25 \cdot 1 \pm 1 \cdot 6$ & $11 \cdot 9 \pm 1 \cdot 2$ & $19 \cdot 6 \pm 1 \cdot 3$ & $15 \cdot 0 \pm I .3$ \\
\hline \multicolumn{8}{|c|}{ Skeletal muscle: } \\
\hline Healthy & 10 & II $0 \pm I \cdot 8$ & $4.7 \pm 0.8$ & $15.3 \pm 0.8$ & $29 \cdot 7 \pm I \cdot 3$ & $5.7 \pm 0.9$ & $7 \cdot 6 \pm 0.9$ \\
\hline Diseased & 10 & $7.5 \pm 0.8$ & $3.5 \pm 0.7$ & $20 \cdot 4 \pm I \cdot 2$ & $21 \cdot 9 \pm 1 \cdot 2$ & $10.0 \pm x \cdot 0$ & $12 \cdot 7 \pm 1 \cdot 9$ \\
\hline \multicolumn{8}{|l|}{ Liver: } \\
\hline Healthy & 10 & $12 \cdot 7 \pm 1 \cdot 6$ & $2 \cdot 5 \pm 0.4$ & $28 \cdot 4 \pm r \cdot 6$ & $22 \cdot 7 \pm 2 \cdot 2$ & $4.7 \pm 0.9$ & $I I \cdot I \pm X \cdot 3$ \\
\hline Diseased & 8 & $12 \cdot I \pm 2 \cdot I$ & $1 \cdot 0 \pm 0.2$ & $33^{\circ} \circ \pm 3 \cdot 3$ & $21 \cdot 1 \pm I \cdot 4$ & $14 \cdot 5 \pm 2 \cdot 6$ & $I I \cdot 9 \pm I \cdot 4$ \\
\hline \multicolumn{8}{|c|}{ Differences significant at: } \\
\hline $5 \%$ level & - & 一 & - & - & Heart & - & $\begin{array}{r}\text { Skeletal } \\
\text { muscle }\end{array}$ \\
\hline $1 \%$ level & - & - & Liver & $\begin{array}{l}\text { Heart, } \\
\text { skeletal } \\
\text { muscle }\end{array}$ & - & $\begin{array}{c}\text { Skeletal } \\
\text { muscle, } \\
\text { liver }\end{array}$ & - \\
\hline $\begin{array}{l}0.1 \% \\
\text { level }\end{array}$ & - & - & Heart & - & $\begin{array}{r}\text { Skeletal } \\
\text { muscle }\end{array}$ & Heart & 一 \\
\hline
\end{tabular}

$\mathrm{I} 6: 0=$ palmitic acid, $\mathrm{I} 6: \mathrm{I}=$ palmitoleic acid, $\mathrm{I} 8: 0=$ stearic acid, $\mathrm{I} 8: \mathrm{I}=$ oleic acid, $\mathrm{I} 8: 2=$ linoleic acid, $20: 4=$ arachidonic acid.

\section{DISCUSSION}

This investigation revealed that the relative proportions of the various phospholipids were unchanged in the heart muscle and skeletal muscle of calves suffering from nutritional muscular dystrophy. Hughes \& Frais (1965) found that muscle from dystrophic mice contained less phosphatidyl choline and more sphingomyelin than did the muscle of healthy mice. In the investigation now reported the proportion of phosphatidyl choline was decreased only in the liver of diseased animals. 
Davenport (1964) studied the composition of phospholipids obtained from ox skeletal muscle. In his investigation phosphatidal compounds were separated from the corresponding phosphatidyl compounds, whereas the method used here did not separate them. The values for the sum of phosphatidyl and phosphatidal choline calculated from the results of Davenport (I964) agreed very well with the values found in the present investigation for phosphatidyl choline (this value also included phosphatidal choline). The value given by Davenport (1964) for cardiolipin agreed very well too, whereas that for sphingomyelin $(3 \%)$ was, however, significantly lower than that found in the present investigation $(7.5 \%)$. In addition to phosphatidyl and phosphatidal ethanolamine, Davenport (1964) found a third ninhydrin-positive fraction that was eluted together with, but, according to Davenport, was not identical with, phosphatidyl ethanolamine. These ninhydrin-positive fractions formed $38.6 \%$ of the total phospholipids. In the present work phosphatidyl ethanolamine formed $29 \%$ of the total phospholipid in the skeletal muscle. Davenport (1964), however, did not find any phosphatidyl serine in the skeletal muscle of the ox.

Gray \& Macfarlane (1958) studied the distribution of phospholipids in the heart muscle of the ox and found the following values as percentages of the total phospholipid: phosphatidyl and phosphatidal choline 42, phosphatidyl and phosphatidal ethanolamine 38 , sphingomyelin 5 , cardiolipin 9 , phosphatidyl serine 5 , and phosphatidyl inositol 2. These values agree fairly well with those found in the present investigation.

As the solvent system of Skipski et al. (1964) was used, cardiolipins moved on the chromatogram together with neutral lipids in a solvent front. The values obtained for cardiolipin also include, therefore, those for phosphatidic acid and phosphatidyl glycerol. The amounts of these two compounds were assayed by using the developing solvent system I of Skipski, Barclay, Reichman \& Good (1967) and found to be very small.

Fatty acid patterns of phosphatidyl choline and phosphatidyl ethanolamine found in the present investigation are in keeping with the findings of others who have investigated the fatty acid patterns of these phospholipid fractions in different animals (van Deenen, 1965; Peng \& Dugan, 1965; Shorland, Body \& Gass, 1966; Glende \& Cornatzer, 1966).

Because the amounts of different types of phospholipids were found to remain nearly unchanged in tissues of diseased calves, it was evident that the changes found earlier (Poukka, 1966) in fatty acid composition of total phospholipids were due to differences in the fatty acid patterns of the two largest phospholipid fractions, which comprised nearly $80 \%$ of the total phospholipids. In calves suffering from nutritional muscular dystrophy the tissue phospholipids seem to contain large amounts of linoleic and arachidonic acids. However, in liver, the arachidonic acid content was unchanged.

In a recent study (Poukka, 1968 ) it was found that the concentration of $\alpha$-tocopherol was very low in tissues of calves suffering from muscular dystrophy. The biochemical role of vitamin $\mathrm{E}$, in the metabolism of unsaturated fatty acids, is still a matter of controversy. Is it a protection against peroxidation or is it linked in some other way to the metabolism of fatty acids, especially to that of acids in the linoleic family? Many 
investigators (Bernhard, Leisinger \& Pedersen, r963; Bieri, I964; Horwitt, 1965) have emphasized the close metabolic relationship of $\alpha$-tocopherol with unsaturated fatty acids, especially with those of the linoleic acid family. Recently Green and his colleagues (Green, Diplock, Bunyan, McHale \& Muthy, 1967; Diplock, Bunyan, McHale \& Green, 1967; Green, Diplock, Bunyan, Muthy \& McHale, 1967; Bunyan, Murrell, Green \& Diplock, I 967) published a long series of studies in which they pointed out that the dietary stress of polyunsaturated fat was without influence on the metabolism of $\alpha$-tocopherol and, on the other hand, the peroxidative loss of polyunsaturated fatty acids was not a general feature of vitamin $E$ deficiency.

\section{REFERENCES}

Bartlett, G. R. (1959). F. biol. Chem. 234, 466.

Bernhard, K., Leisinger, S. \& Pedersen, W. (1963). Helv. chim. Acta 46, I767.

Bieri, J. G. (1964). Fedn Proc. Fedn Am. Socs exp. Biol. 23, 394.

Bligh, E. G. \& Dyer, W. J. (1959). Can. F. Biochem. Physiol. 37, 9 Ir.

Bunyan, J., Murrell, E. A., Green, J. \& Diplock, A. T. (1967). Br. F. Nutr. 21, 475.

Davenport, J. B. (1964). Biochem. F. 90, 116.

Diplock, A. T., Bunyan, J., McHale, D. \& Green, J. (1967). Br. F. Nutr. 21, ro3.

Doizaki, W. M. \& Zieve, L. (I963). Proc. Soc. exp. Biol. Med. I13, 91.

Glende, E. A. Jx \& Cornatzer, W. E. (1966). Biochim. biophys. Acta 125, 3 10.

Gray, G. M. \& Macfarlane, M. G. (1958). Biochem. F. 7o, 409.

Green, J., Diplock, A. T., Bunyan, J., McHale, D. \& Muthy, I. R. (1967). Br. F. Nutr. $21,69$.

Green, J., Diplock, A. T., Bunyan, J., Muthy, I. R, \& McHale, D. (I967). Br. F. Nutr. 2 I, 497.

Horwitt, M. K. (1965). Fedn Proc. Fedn Am. Socs exp. Biol. 24, 68.

Hughes, B. P. \& Frais, F. F. (1965). Biochem. F. 96, 6 P.

Malins, D. C. (1966). Prog. Chem. Fats 8, 303.

Neudoerffer, T. S. \& Lea, C. H. (1966). F. Chromat. 2r, 138.

Oksanen, H. E. (1965). Acta vet. scand. 6, Suppl. 2.

Peng, C. Y. \& Dugan, L. R. Jr (1965). F. Am Oil. Chem. Soc. 42, 533.

Poukka, R. (1966). Br. f. Nutr. 20, 245.

Poukka, R. (1968). Br. F. Nutr. 22, 423 .

Shorland, F. B., Body, D. R. \& Gass, J. P. (I 966). Biochim. biophys. Acta 125, 217.

Skipski, V. P., Barclay, M., Reichman, E. S. \& Good, J. J. (1967). Biochim. biophys. Acta 137, 80.

Skipski, V. P., Peterson, R. F. \& Barclay, M. (1964). Biochem. F. 9o, 374.

Stahl, E. (1965). Thin-Layer Chromatography. New York: Academic Press Inc.

Stoffel, W., Chu, F. \& Ahrens, E. H. Jr (I959). Analyt. Chem. 3r, 307.

van Deenen, L. L. M. (1965). Prog. Chem. Fats. 8, 1.

Woodford, F. P. \& van Gent, C. M. (1959-60). F. Lipid. Res. I, r88 